\title{
Penerapan Metode Moora Pada Sistem Pendukung Keputusan Pemilihan Media Promosi Sekolah (Studi Kasus: SMK Airlangga Balikpapan)
}

\author{
Isa Rosita $^{1^{*}}$, Gunawan $^{2}$, Desi Apriani ${ }^{3}$ \\ ${ }^{1,2,3}$ Program Studi Informatika, Fakultas Ilmu Komputer, Universitas Mulia \\ *isarosita@universitasmulia.ac.id
}

\begin{abstract}
School promotion is an activity that aims to communicate educational products to consumers or prospective students. Promotional activities require strategic policies to maximize promotional results, therefore an analysis of the selection of the right promotional media needs to be carried out. This study aims to determine the priority ranking of school promotion media by implementing the Multi-Objective Optimization on The Basic of Ratio (MOORA) method in a decision support system with a case study at SMK Airlangga Balikpapan. MOORA is used in the calculation process which produces output in the form of promotional media rankings to be recommended to the school promotion team as consideration for selecting the right promotional media. The criteria used in determining the priority of school promotion media include the cost of making the media, the time of promotion, the reach of media distribution, the completeness of information, and flexibility. Alternative promotional media used in this research are brochures, posters, billboards, banners, and newspaper advertisements. Based on the research results, the MOORA method can be applied to the decision support system for selecting school promotion media and produce output in the form of priority ranking for school promotion media.
\end{abstract}

Keywords: decision support system, MOORA, promotion media

\begin{abstract}
Abstrak
Promosi sekolah merupakan suatu kegiatan untuk mengkomunikasikan produk pendidikan kepada konsumen atau calon siswa. Kegiatan promosi memerlukan kebijakan-kebijakan strategis agar dapat memaksimalkan hasil promosi, karenanya analisis terhadap pemilihan media promosi yang tepat perlu dilakukan. Penelitian ini bertujuan untuk menentukan peringkat prioritas media promosi sekolah dengan mengimplementasikan metode Multi Objective Optimization on The Basic of Ratio (MOORA) dalam sistem pendukung keputusan dengan studi kasus pada SMK Airlangga Balikpapan. MOORA digunakan dalam proses perhitungan yang menghasilkan keluaran berupa peringkat media promosi untuk direkomendasikan kepada tim promosi sekolah sebagai pertimbangan pemilihan media promosi yang tepat. Kriteria yang digunakan dalam penentuan prioritas media promosi sekolah meliputi biaya pembuatan media, waktu promosi, jangkauan penyebaran media, kelengkapan informasi dan fleksibilitas. Alternatif media promosi yang digunakan dalam penelitian ini adalah brosur, poster, baliho, spanduk dan iklan koran. Berdasarkan hasil penelitian, metode MOORA dapat diterapkan pada sistem pendukung keputusan pemilihan media promosi sekolah dan dapat menghasilkan keluaran berupa peringkat prioritas media promosi sekolah.
\end{abstract}

Kata kunci: sistem pendukung keputusan, MOORA, media promosi.

\section{Pendahuluan}

Promosi merupakan suatu kegiatan untuk mengkomunikasikan produk kepada konsumen, sehingga kegunaan serta kualitas dari produk yang dihasilkan dapat dirasakan oleh konsumen [1]. Saat ini kegiatan promosi tidak hanya dilakukan oleh perusahaanperusahaan penjual barang atau jasa, institusi pendidikan juga kerap melakukan promosi dalam rangka menarik minat calon pengguna jasa pendidikan. Salah satu institusi pendidikan yang melakukan promosi atas jasa yang mereka tawarkan adalah sekolah menengah swasta. SMK Airlangga Balikpapan adalah salah satu sekolah swasta di Balikpapan yang setiap tahunnya melakukan kegiatan promosi sekolah dalam rangka memperkenalkan sekolah dan menjaring peserta didik baru. 
Kebijakan-kebijakan strategis dalam rangka memaksimalkan hasil promosi diperlukan dalam kegiatan promosi sekolah. Namun dalam menentukan kebijakan tersebut bukan hal yang mudah. Permasalahan yang sering dialami oleh tim promosi adalah kurang maksimalnya hasil dari promosi karena pemilihan media promosi masih dilakukan tanpa pertimbangan strategi yang matang. Hal ini mengakibatkan biaya promosi yang besar dengan hasil penjaringan calon siswa yang sedikit. Oleh karena itu, dibutuhkan sebuah sistem yang dapat mendukung proses pengambilan keputusan dalam menentukan kebijakan strategi promosi sekolah.

Sistem pendukung keputusan (SPK) berbasis komputer cukup banyak diterapkan dalam penentuan kebijakan diberbagai bidang, seperti dalam bidang ekonomi [2], industri [3], pendidikan [4] dan lain-lain, termasuk dalam pemilihan media promosi [5]. Secara umum, SPK adalah sebuah sistem berbasis komputer yang memanfaatkan data dan model untuk menyelesaikan masalahmasalah yang terstruktur. Secara khusus, SPK adalah sebuah sistem yang mendukung kerja para pengambil keputusan dalam memecahkan masalah semi terstruktur dengan cara memberikan informasi maupun alternatif keputusan terhadap permasalahan tertentu [6].

Multi-Objective Optimization by Ratio Analysis (MOORA) adalah salah satu metode yang dapat digunakan untuk membantu proses pengambilan keputusan dalam SPK. Metode MOORA dikembangkan pertama kali oleh Brauers yang menerapkannya dalam proses pengambilan keputusan dengan multikriteria [7]. Kelebihan metode ini salah satunya adalah fleksibilitas yang tinggi dan tingkat selektifitas yang baik. Hal ini disebabkan MOORA mampu menentukan tujuan dari kriteria yang saling bertolak belakang, dimana kriteria dapat bernilai menguntungkan (benefit) atau yang tidak menguntungkan (cost). Selain itu, MOORA juga memiliki kemampuan memisahkan unsur subjektif dari suatu proses evaluasi secara mudah ke dalam kriteria bobot keputusan yang memiliki beberapa atribut pengambil keputusan [8].

\section{Penelitian ini bertujuan untuk} menentukan peringkat prioritas media promosi sekolah dengan mengimplementasikan metode MultiObjective Optimization on The Basic of Ratio (MOORA) ke dalam sebuah sistem pendukung keputusan dengan studi kasus pada SMK Airlangga Balikpapan. MOORA digunakan dalam proses perhitungan yang menghasilkan keluaran berupa peringkat media promosi untuk direkomendasikan kepada tim promosi sekolah sebagai pertimbangan pemilihan media promosi yang tepat.

\section{Metoda Penelitian}

\subsection{Gambaran Umum Sistem}

Penelitian ini dilakukan di Laboratorium A, Fakultas Ilmu Komputer, Universitas Mulia Balikpapan. Implementasi sistem dilakukan dengan menggunakan aplikasi Visual Basic 2019 Community. Aplikasi Microsoft Excel 2016 digunakan sebagai alat bantu pengujian akurasi perhitungan sistem. Implementasi dan pengujian sistem dilakukan pada perangkat komputer jinjing dengan CPU $2 \mathrm{GHz}$ dan 12 GB RAM, serta sistem operasi Windows 10, 64 bit.

Beberapa batasan diterapkan dalam penelitian ini agar ruang lingkup penelitian tidak meluas, yaitu:

1. Masukan sistem berupa data kriteria dan alternatif media promosi sekolah

2. Data yang berhubungan dengan penentuan kriteria dan alternatif yang digunakan dalam peneltian ini didapat dari hasil pengumpulan data pada SMK Airlangga Balikpapan

3. Kriteria yang digunakan meliputi biaya pembuatan media, waktu promosi, jangkauan penyebaran media, kelengkapan informasi dan fleksibilitas. Alternatif media promosi yang digunakan dalam pengujian adalah brosur, poster, baliho, spanduk dan iklan koran

4. Keluaran sistem berupa peringkat prioritas media promosi berdasarkan hasil perhitungan metode MOORA.

Gambaran umum alur sistem yang diterapkan dalam penelitian ini ditunjukkan pada Gambar 1. 


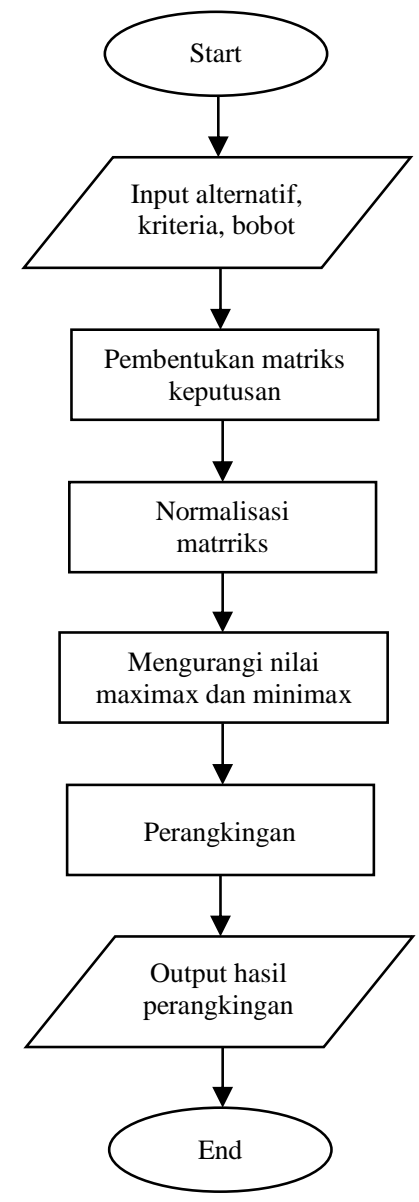

Gambar 1. Gambaran Umum Alur Sistem

\subsection{Sistem Pendukung Keputusan (SPK)}

Sistem pendukung keputusan (SPK) secara umum adalah sebuah sistem berbasis komputer yang interaktif, yang membantu mengambil keputusan dengan memanfaatkan data dan model untuk menyelesaikan masalah-masalah yang terstruktur. Secara khusus, SPK adalah sebuah sistem yang mendukung kerja seorang manajer maupun sekelompok manajer dalam memecahkan masalah semi terstruktur dengan cara memberikan informasi ataupun usulan menuju pada keputusan tertentu [6]. Pada dasarnya SPK merupakan pengembangan lebih lanjut dari Sistem Informasi Manajemen terkomputerisasi yang dirancang sedemikian rupa sehingga bersifat interaktif dengan pemakainya. Interaktif dengan tujuan untuk memudahkan integrasi antara berbagai komponen dalam proses pengambilan keputusan seperti prosedur, kebijakan, analisis, pengalaman dan wawasan manajer untuk mengambil keputusan yang lebih baik. [9]
Beberapa karakteristik sistem pendukung keputusan, yaitu: [10]

1. Interaktif

Karakteristik ini mengharuskan sebuah SPK memiliki tampilan antar muka yang komunikatif, sehingga memudahkan pemakai dalam mengakses data dan informasi yang dibutuhkan secara cepat.

2. Fleksibel

Fleksibel berarti SPK memiliki kemampuan untuk mengolah sebanyak mungkin variabel masukan, serta memberikan keluaran berupa alternatifalternatif keputusan yang dibutuhkan pengambil keputusan.

3. Data kualitas

Karakteristik ini mengharuskan SPK memiliki kemampuan mengkuantisasi data kualitas yang bersifat subyektif dari masukan pemakai. Misalnya, penilaian terhadap keindahan yang bersifat kualitas, dapat dikonversi menjadi sebuah nilai kuantitas dengan memberikan nilai bobot dalam bentuk angka, seperti 80 atau 95.

4. Prosedur Pakar

Dalam sebuah SPK, diperlukan suatu prosedur tertentu yang dirancang berdasarkan kepakaran atau keilmuan seseorang atau sekelompok orang yang ahli dalam menyelesaikan masalah yang menjadi pembahasan SPK tersebut.

\subsection{Multi Objective Optimization on The Basic of Ratio (MOORA)}

Multi-Objective Optimization on The Basic of Ratio Analysis (MOORA) adalah sistem dengan multi-objektif, yang di dalamnya memiliki dua atau lebih atribut yang saling bertentangan. MOORA melakukan optimalisasi terhadap atributatribut tersebut dengan menerapkan perhitungan matematika yang kompleks, sehingga didapatkan keluaran berupa pemecahan masalah yang diinginkan [7]. Metode ini melakukan pemisahan subjektifitas dari suatu proses penilaian ke bentuk kriteria berbobot dengan beberapa atribut pengambilan keputusan dengan cara yang lebih mudah dipahami. Metode ini juga memiliki tingkat fleksibilitas yang tinggi dalam pengolahan variabelnya. [8] 
Langkah-langkah dalam metode MOORA terdiri dari: [11]

1. Membuat matriks keputusan. Matriks keputusan mewakilkan semua informasi yang tersedia untuk setiap atribut dalam bentuk matriks. Persamaan menunjukkan sebuah matriks $X_{m x n}$, Dimana $x_{i j}$ adalah pengukuran kinerja dari alternatif ke-i pada atribut ke-j, m adalah jumlah alternatif dan $\mathrm{n}$ adalah jumlah atribut/kriteria. Selanjutnya, dilakukan perbandingan antara setiap kinerja dari alternatif yang ada pada atribut dengan penyebut yang mewakili semua alternatif dari atribut tersebut.

$$
\boldsymbol{X}=\left[\begin{array}{ccccc}
x_{11} & \ldots & x_{1 i} & \ldots & x_{1 n} \\
\vdots & & \vdots & \ddots & \vdots \\
x_{i 1} & \ldots & x_{i j} & \ldots & x_{j n} \\
\vdots & \ddots & \vdots & \ddots & \vdots \\
x_{m 1} & \ldots & x_{m i} & \ldots & x_{m n}
\end{array}\right]
$$

Keterangan:

$\mathrm{x}_{\mathrm{ij}}$ : respon alternatif $\mathrm{j}$ pada kriteria $\mathrm{i}$

$\mathrm{i}: 1,2,3, \ldots, \mathrm{n}$ adalah inisialisasi urutan kriteria atau atribut

$\mathrm{j}: 1,2,3, \ldots, \mathrm{m}$ adalah inisialisasi urutan alternatif

$\mathrm{X}$ : matriks keputusan

2. Normalisasi. Tahapan ini dilakukan untuk mendapatkan nilai element matriks yang seragam dengan cara menyatukan setiap element matriks. Persamaan (2) digunakan untuk menghitung matriks normalisasi.

$$
X^{*}{ }_{i j}=\frac{x_{i j}}{\sqrt{\left[\sum_{\mathrm{j}=1}^{\mathrm{m}} x_{\mathrm{ij}}^{2}\right]}}
$$

Keterangan:

$\mathrm{x}_{\mathrm{ij}}$ : matriks alternatif $\mathrm{j}$ dengan kriteria i

i : $1,2,3, \ldots, \mathrm{n}$ adalah inisialisasi urutan kriteria atau atribut

$\mathrm{j}: 1,2,3, \ldots, \mathrm{m}$ adalah inisialisasi urutan alternatif

$\mathrm{X}_{\mathrm{ij}}^{*}$ :Matriks Normalisasi alternatif $\mathrm{j}$ dengan kriteria $\mathrm{i}$

3. Mengurangi nilai maximax dan minimax. Pada tahapan ini terdapat dua kondisi yang mungkin terjadi yang masing- masing memiliki perhitungan yang berbeda. Kondisi tersebut yaitu:

a Tidak adanya nilai bobot yang dimiliki atribut atau kriteria di setiap alternatif. Pada situasi ini, maka dilakukan pengurangan nilai maksimum dan minimum pada setiap baris. Hal ini dilakukan untuk mendapatkan rangking dari setiap baris. Persamaan (3) digunakan dalam proses ini.

$$
y_{j}^{*}=\sum_{i=1}^{i=g} x_{i j}^{*}-\sum_{i=g+1}^{i=n} x_{i j}^{*}
$$

Keterangan:

i : $1,2,3, \ldots$, g adalah kriteria atau atribut maximized

$\mathrm{j}: \mathrm{g}+1, \mathrm{~g}+2, \mathrm{~g}+3, \ldots, \mathrm{n}$ adalah kriteria atau atribut minimized

$\mathrm{y}^{*}{ }_{\mathrm{j}}$ : Matriks normalisasi hasil pengurangan maximaize dan minimize alternatif $\mathrm{j}$

b Atribut atau kriteria di setiap alternatif memiliki atau diberikan nilai bobot kepentingan. Pada kondisi ini maka pemberian nilai bobot dilakukan dengan ketentuan nilai bobot jenis kriteria minimum harus lebih kecil dari nilai bobot kriteria maksimum. Koefisien signifikasi diberikan pada atribut yang lebih penting dengan cara melakukan perkalian nilai bobot dengan nilai koefisiensi tersebut. Persamaan (4) digunakan untuk menghitung bagian ini.

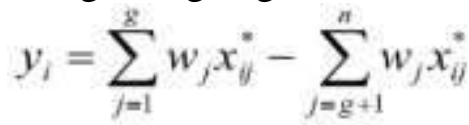

Keterangan:

i : $1,2,3, \ldots$, g adalah kriteria atau atribut maximized

$\mathrm{j}: \mathrm{g}+1, \mathrm{~g}+2, \mathrm{~g}+3, \ldots, \mathrm{n}$ adalah kriteria atau atribut minimized

$\mathrm{w}_{\mathrm{j}}$ : nilai bobot alternatif $\mathrm{j}$

$\mathrm{y}_{\mathrm{i}}$ : nilai penilaian yang sudah dinormalisasi dari alternatif $\mathrm{j}$ terhadap semua atribut

4. Pemeringkatan atau perangkingan. Total nilai maksimal (atribut benefit) dalam sebuah matriks keputusan dapat mengakibatkan nilai $y_{i}$ bernilai positif 
atau negatif. Pada tahap ini dilakukan pemeringkatan terhadap nilai $\mathrm{y}_{\mathrm{i}}$, dimana nilai $y_{i}$ tertinggi menjadi penanda alternatif terbaik, sedangkan Alternatif dengan nilai $y_{i}$ terendah adalah alternatif terburuk.

\section{Hasil Penelitian}

Sistem pendukung keputusan yang dibangun dalam penelitian ini diimplementasikan menggunakan aplikasi Visual Basic 2019 Community. MOORA digunakan sebagai metode perhitungan penentuan peringkat prioritas. Kriteria, alternatif dan nilai bobot kriteria didapat dari hasil wawancara dengan tim promosi SMK Airlangga Balikpapan sebagai pembuat keputusan (decission maker). Nilai bobot kriteria beserta jenisnya dan skala penilaian nilai alternatif dapat dilihat pada Tabel 1 dan 2.

Tabel 1. Nilai Bobot dan Jenis Kriteria

\begin{tabular}{ccc}
\hline Bobot & Jenis & Kriteria \\
\hline 0,15 & Benefit & Waktu \\
0,25 & Benefit & Jangkauan \\
0,15 & Benefit & Kelengkapan Informasi \\
0,10 & Benefit & Fleksibilitas \\
0,35 & Cost & Biaya \\
\hline
\end{tabular}

Tabel 2. Skala Penilaian

\begin{tabular}{ccccc}
\hline & $\begin{array}{c}\text { Tidak } \\
\text { Penting }\end{array}$ & $\begin{array}{c}\text { Kurang } \\
\text { Penting }\end{array}$ & Penting & $\begin{array}{c}\text { Sangat } \\
\text { Penting }\end{array}$ \\
\hline Nilai & 1 & 2 & 3 & 4 \\
\hline
\end{tabular}

Tampilan halaman input nilai kriteria setiap alternatif ditunjukkan pada pada Gambar 2. Pada halaman ini user melakukan input data yang berupa skala penilaian sebagaimana Tabel 2.

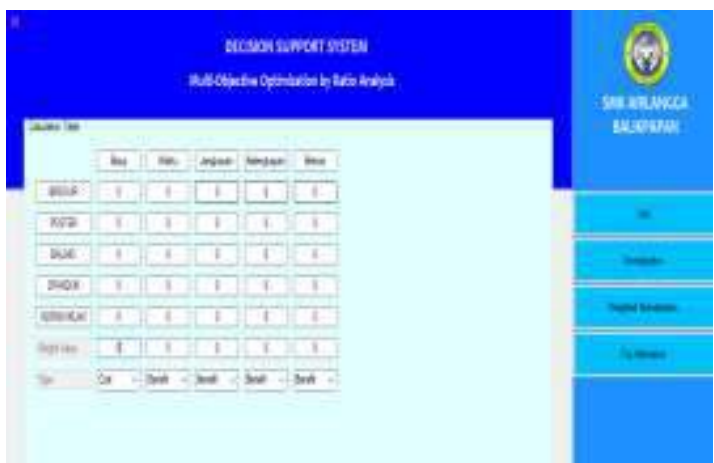

Gambar 2. Tampilan Halaman Input Nilai Kriteria
Selanjutnya sistem akan melakukan proses penentuan peringkat dengan metode MOORA sebagaimana alur sistem yang tergambar pada Gambar 1. Pada penelitian ini sistem diuji dengan menggunakan data input seperti yang ditunjukkan Tabel 3. Pada Tabel 3, alternatif dikodekan dengan ketentuan angka 1 mewakili Brosur, 2 mewakili Poster, 3 mewakili Baliho, 4 mewakili Spanduk, dan 5 mewakili Iklan koran.

Tabel 3. Data Input Pengujian Sistem dari Tim Promosi Sekolah

\begin{tabular}{llllll}
\hline \multicolumn{1}{c}{ Kriteria } & \multicolumn{5}{c}{ Alternatif } \\
& $\mathbf{1}$ & $\mathbf{2}$ & $\mathbf{3}$ & $\mathbf{4}$ & $\mathbf{5}$ \\
\hline Biaya & 4 & 4 & 1 & 3 & 4 \\
Waktu & 3 & 3 & 2 & 3 & 3 \\
Jangkauan & 3 & 3 & 2 & 2 & 2 \\
Kelengkapan & 3 & 2 & 1 & 3 & 1 \\
Fleksibilitas & 3 & 2 & 2 & 2 & 2 \\
\hline
\end{tabular}

Dari data pada Tabel 3 sistem melakukan perhitungan dengan langkahlangkah metode MOORA dengan hasil sebagai berikut:

1. Matriks keputusan

$$
\left[\begin{array}{lllll}
4 & 3 & 3 & 3 & 3 \\
4 & 3 & 3 & 2 & 2 \\
1 & 2 & 2 & 1 & 2 \\
3 & 3 & 2 & 3 & 2 \\
4 & 3 & 2 & 1 & 2
\end{array}\right]
$$

2. Matriks normalisasi dan normalisasi terbobot berdasarkan jenis kriteria

$$
\begin{gathered}
{\left[\begin{array}{lllll}
0,5252 & 0,4743 & 0,5477 & 0,6123 & 0,60 \\
0,5252 & 0,4743 & 0,5477 & 0,4082 & 0,40 \\
0,1313 & 0,3162 & 0,3651 & 0,2041 & 0,40 \\
0,3939 & 0,4743 & 0,3651 & 0,6123 & 0,40 \\
0,5252 & 0,4743 & 0,3651 & 0,2041 & 0,40
\end{array}\right]} \\
{\left[\begin{array}{lllll}
-0,1838 & 0,0711 & 0,1369 & 0,0918 & 0,06 \\
-0,1838 & 0,0711 & 0,1369 & 0,0612 & 0,04 \\
-0,0459 & 0,0474 & 0,0912 & 0,0306 & 0,04 \\
-0,1378 & 0,0711 & 0,0912 & 0,0918 & 0,04 \\
-0,1838 & 0,0711 & 0,0912 & 0,0306 & 0,04
\end{array}\right]}
\end{gathered}
$$

3. Mengurangi nilai maximax dan minimax. Proses ini dilakukan dengan menerapkan persamaan (4) pada data hasil normalisasi terbobot. Hasil perhitungan pada tahapan dapat dilihat pada Tabel 4. 
Tabel 4. Perhitungan nilai $Y_{i}$

\begin{tabular}{|c|c|c|}
\hline Brosur & $\begin{array}{l}(-0,1838+0,0711+ \\
0,1369+0,0918+0,06)\end{array}$ & 0,176 \\
\hline Poster & $\begin{array}{l}(-0,1838+0,0711+ \\
0,1369+0,0612+0,04)\end{array}$ & 0,125 \\
\hline Baliho & $\begin{array}{l}(-0,0459+0,0474+ \\
0,0912+0,0306+0,04)\end{array}$ & 0,163 \\
\hline Spanduk & $\begin{array}{l}(-0,1378+0,0711+ \\
0,0912+0,0918+0,04)\end{array}$ & 0,156 \\
\hline $\begin{array}{l}\text { Iklan } \\
\text { Koran }\end{array}$ & $\begin{array}{l}(-0,1838+0,0711+ \\
0,0912+0,0306+0,04)\end{array}$ & 0,049 \\
\hline
\end{tabular}

4. Perangkingan. Dari hasil perhitungan nilai $Y_{i}$ pada Tabel 4 didapat hasil perangkingan sebagaimana Tabel 5. Hasil ini adalah hasil akhir dari proses perhitungan yang menjadi keluaran sistem.

Tabel 5. Hasil Perangkingan

\begin{tabular}{lcc}
\hline \multicolumn{1}{c}{ Alternatif } & $\mathbf{Y}_{\mathbf{i}}$ & Rangking \\
\hline Brosur & 0,176 & 1 \\
Poster & 0,125 & 4 \\
Baliho & 0,163 & 2 \\
Spanduk & 0,156 & 3 \\
Iklan Koran & 0,049 & 5 \\
\hline
\end{tabular}

Tampilan hasil akhir perangkingan ditunjukkan pada Gambar 3.

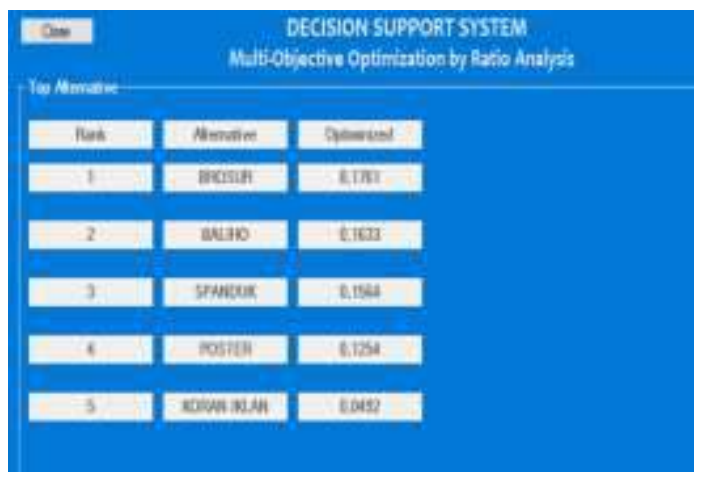

Gambar 3. Hasil Keluaran Sistem dari Data Pengujian

Pengujian terhadap akurasi hasil perhitungan sistem juga dilakukan untuk mengetahui akurasi hasil perhitungan. Pengujian dilakukan dengan membandingkan hasil perhitungan manual dan perhitungan sistem dengan beberapa skenario data pengujian. Data pengujian akurasi menggunakan dua skenario masukan data yang diperlihatkan pada Tabel 6 dan 7 .

Tabel 6. Data Input Pengujian Skenario I

\begin{tabular}{llllll}
\hline \multirow{2}{*}{ Kriteria } & \multicolumn{5}{c}{ Alternatif } \\
& $\mathbf{1}$ & $\mathbf{2}$ & $\mathbf{3}$ & $\mathbf{4}$ & $\mathbf{5}$ \\
\hline Biaya & 4 & 4 & 1 & 3 & 4 \\
Jaktu & 3 & 3 & 2 & 3 & 3 \\
Kelengkapan & 3 & 2 & 1 & 3 & 1 \\
Fleksibilitas & 3 & 2 & 2 & 2 & 2 \\
\hline
\end{tabular}

Tabel 7. Data Input Pengujian Skenario II

\begin{tabular}{llllll}
\hline \multirow{2}{*}{ Kriteria } & \multicolumn{5}{c}{ Alternatif } \\
& $\mathbf{1}$ & $\mathbf{2}$ & $\mathbf{3}$ & $\mathbf{4}$ & $\mathbf{5}$ \\
\hline Biaya & 1 & 2 & 1 & 1 & 2 \\
Waktu & 3 & 2 & 3 & 1 & 3 \\
Jangkauan & 2 & 3 & 2 & 2 & 4 \\
Kelengkapan & 3 & 2 & 4 & 3 & 2 \\
Fleksibilitas & 3 & 2 & 2 & 2 & 2 \\
\hline
\end{tabular}

Dari hasil pengujian akurasi diketahui bahwa hasil perhitungan manual dan sistem tidak memiliki perbedaan. Hal ini menunjukkan bahwa sistem telah benar melakukan perhitungan dengan akurasi $100 \%$. Hasil pengujian dapat dilihat pada Tabel 8 dan 9.

Tabel 8. Hasil Pengujian Akurasi Perhitungan Sistem Skenario I

\begin{tabular}{cccc}
\hline Alternatif & $\begin{array}{c}\text { Hasil } \\
\text { Rangking } \\
\text { Sistem }\end{array}$ & $\begin{array}{c}\text { Hasil } \\
\text { Rangking } \\
\text { Manual }\end{array}$ & Hasil \\
\hline $\mathbf{1}$ & 1 & 1 & Sesuai \\
$\mathbf{2}$ & 4 & 4 & Sesuai \\
$\mathbf{3}$ & 2 & 2 & Sesuai \\
$\mathbf{4}$ & 3 & 3 & Sesuai \\
$\mathbf{5}$ & 5 & 5 & Sesuai \\
\hline
\end{tabular}

Tabel 9. Hasil Pengujian Akurasi Perhitungan Sistem Skenario II

\begin{tabular}{cccc}
\hline Alternatif & $\begin{array}{c}\text { Hasil } \\
\text { Rangking } \\
\text { Sistem }\end{array}$ & $\begin{array}{c}\text { Hasil } \\
\text { Rangking } \\
\text { Manual }\end{array}$ & Hasil \\
\hline $\mathbf{1}$ & 2 & 2 & Sesuai \\
$\mathbf{2}$ & 5 & 5 & Sesuai \\
$\mathbf{3}$ & 1 & 1 & Sesuai \\
$\mathbf{4}$ & 4 & 4 & Sesuai \\
$\mathbf{5}$ & 3 & 3 & Sesuai \\
\hline
\end{tabular}




\section{Kesimpulan}

Berdasarkan hasil penelitian yang telah dilakukan, dapat disimpulkan bahwa metode Multi-Objective Optimization on The Basic of Ratio Analysis (MOORA) telah berhasil diimplementasikan pada sistem pendukung keputusan pemilihan media promosi sekolah di SMK Airlangga Balikpapan. Dari hasil perhitungan sistem sesuai dengan bobot kriteria dan alternatif masukan yang didapat dari tim promosi sekolah, didapat bahwa media brosur adalah alternatif yang memiliki peringkat prioritas tertinggi. Dari hasil pengujian akurasi perhitungan sistem didapatkan hasil akurasi perhitungan sebesar $100 \%$.

\section{Saran}

Penelitian selanjutnya dapat dilakukan dengan data alternatif dan kriteria yang lebih kompleks, sehingga analisis terhadap hasil implementasi metode dapat lebih baik.

\section{Daftar Pustaka}

[1] Firdaus and R. Rahmat, "Tinjauan Pelaksanaan Promosi pada PT. Pindad (Persero) Bandung," Universitas Widyatama Bandung, 2014.

[2] K. Prayitno and W. Pujiyono, "Sistem Pendukung Keputusan dengan Pemetaan untuk Meningkatkan Ekonomi Berbasis Industri Kecil," J. Sarj. Tek. Inform., vol. 2, no. 1, pp. 866-877, 2014.

[3] E. Handayani, H. L. Napitupulu, and I. Siregar, "Perancangan Sistem Pendukung Keputusan Pengadaan Bahan Baku Pada PT. XYZ Unit Percetakan," J. Tek. Ind. USU, vol. 3, no. 4, pp. 9-17, 2013.

[4] P. Sianturi, P. Ramadhani, and N. W. Al-hafiz, "Sistem Pendukung Keputusan Penentuan Penerima Bantuan Operasional Penyelengaraan (BOP) PAUD (Pendidikan Anak Usia Dini) Menerapkan Metode Electre (Studi Kasus: Dinas Pendidikan Kabupaten Simalungun)," KOMIK (Konferensi Nas. Teknol. Inf. dan
Komputer), vol. I, pp. 20-26, 2017.

[5] Gunawan, "Sistem Pendukung Keputusan Pemilihan Media Cetak Sebagai Sarana Promosi Menggunakan Metode Analytical Hierarchy Process dan Weighted Product," J. Teknol. Terpadu, vol. 7, no. 1, pp. 1-9, 2019.

[6] Amrizal, Victor, and Q. Aini, Kecerdasan Buatan. Jakarta: Halaman Moeka, 2013.

[7] W. K. M. Brauers, E. K. Zavadskas, F. Peldschus, and Z. Turskis, "MultiObjective Decision-Making For Road Design," TRANSPORT, vol. 23, no. 3, pp. 183-193, 2008.

[8] U. K. Mandal and B. Sarkar, "Selection of Best Intelligent Manufacturing System (IMS) Under Fuzzy Moora Conflicting MCDM Environment," Int. J. Emerg. Technol. Adv. Eng., vol. 2, no. 9, pp. 301-310, 2012.

[9] K. Suryadi and M. A. Ramdhani, Sistem Pendukung Keputusan. Bandung: PT. Remaja Rosdakarya, 2010.

[10] B. S. D. Oetomo, Perencanaan dan Pengembangan Sistem Informasi, I. Yogyakarta: Andi, 2002.

[11] S. W. Pasaribu, E. Rajagukguk, M. Sitanggang, R. Rahim, and L. A. Abdillah, "Implementasi MultiObjective Optimization On The Basis Of Ratio Analysis (MOORA) Untuk Menentukan Kualitas Buah Mangga Terbaik," J. Ris. Komput., vol. 5, no. 1, pp. 50-55, 2018. 